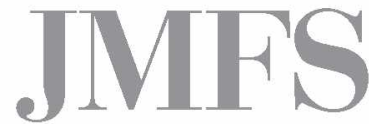

Journal of Management and Financial Sciences
Volume X

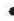

Issue 29 (September 2017)

pp. 131-142

Warsaw School of Economics

Collegium of Management and Finance

\title{
Jacek Grzywacz
}

Collegium of Business Administration

Warsaw School of Economics

Ewa Jagodzińska-Komar

Powszechna Kasa Oszczędności Bank Polski SA

\section{The Role of the Polish Private Equity Sector in the CEE Region}

Abstract

The aim of the article is to analyse the position of the Polish private equity sector as a leading player in the CEE region and to assess the impact of these funds on economic development. It has been pointed out that the fund sector is operating in an increasingly unpredictable environment (which could be seen during the financial crisis) and operates based on demanding regulations and growing risk. The paper presents the role of private equity funds in the CEE region, which by 2004 had seen a noticeably faster growth than in Western Europe, due to the transition to a market economy. The Polish private equity market in the CEE region was further analysed, which as the largest economy in the CEE region is a very attractive place for investors. The conclusions and directions of the role of private equity funds were presented, and it was emphasised that Poland and the whole CEE region are at an early stage of their market development, but their distance to Western Europe decreases from year to year. Currently, the CEE private equity market in the most developed countries offers great opportunities to its investors thanks to high competition, high growth potential and comprehensive solutions. 
Keywords: private equity, CEE region, European Investment Fund, European Private Equity and Venture Capital Association (EVCA)

JEL Codes: F30, G15, G24

\section{Introduction}

Poland is surely the most attractive economy in the CEE region due to its size (the biggest in the region), well developed capital market and stable banking sector. Its market has developed institutions that support private equity funds, such as the European Investment Fund. Every year the country closes the gap dividing it from Western European economies. We need to bear in mind that Poland is the only economy in Europe that reported growth over the years of the global financial crisis, and this stable economic growth has made it the major private equity market in the CEE region. According to the $\mathrm{KPMG}^{1}$ Report, the value of private equity funds in our country in 2015 reached ca. EUR $803.5 \mathrm{~m}$ (it tripled compared to 2014), more than a half of the total value of all transactions made in the region ( (Poland's GDP represents $35 \%$ of the GDP of the whole CEE region). Noteworthy, Poland is the most attractive target for investing private equity funds in the region as concluded in the KPMG Report of $2014^{2}$ and private equity funds impact economic growth of the country where they invest, targeting highly innovative and dynamic enterprises.

The main goal of the paper is to assess the role of the Polish private equity sector in the CEE region and identify its growth outlook for the forthcoming years.

The paper discusses conclusions concerning the growth of the private equity sector in Poland based on the latest data published by Eurostat, the European Commission, the International Monetary Fund, and the European Private Equity and Venture Capital Association (EVCA).

1 Private Equity in Poland 2016. Trends and Opportunities, KPMG Report, Edition 2016, https:// assets.kpmg.com/content/dam/kpmg/pdf/2016/06/pl-raport-kpmg-rynek-private-equity-w--polsce-2016. pdf [Polish language version], accessed on 22.03.2017.

2 Private Equity in Poland: Facts and Opinions, KPMG Report, Edition 2014, https://assets.kpmg. $\mathrm{com} /$ content/dam/kpmg/pdf/2014/06/Rynek-Private-Equity-w-Polsce-fakty-a-opinie-2014-KPMG-wPolsce.pdf [Polish language version], accessed on 22.03.2017. 


\section{Role of Private Equity Funds in the CEE Region}

Private equity funds came back to the CEE region in 1990 when Central and East European markets opened up to foreign markets and adopted principles of the market economy. We need to stress, however, that the private equity market in the CEE region is still at its initial development stage.

\section{Diagram 1. Private equity investment in the CEE region between 2012 and 2015 (in million EUR)}

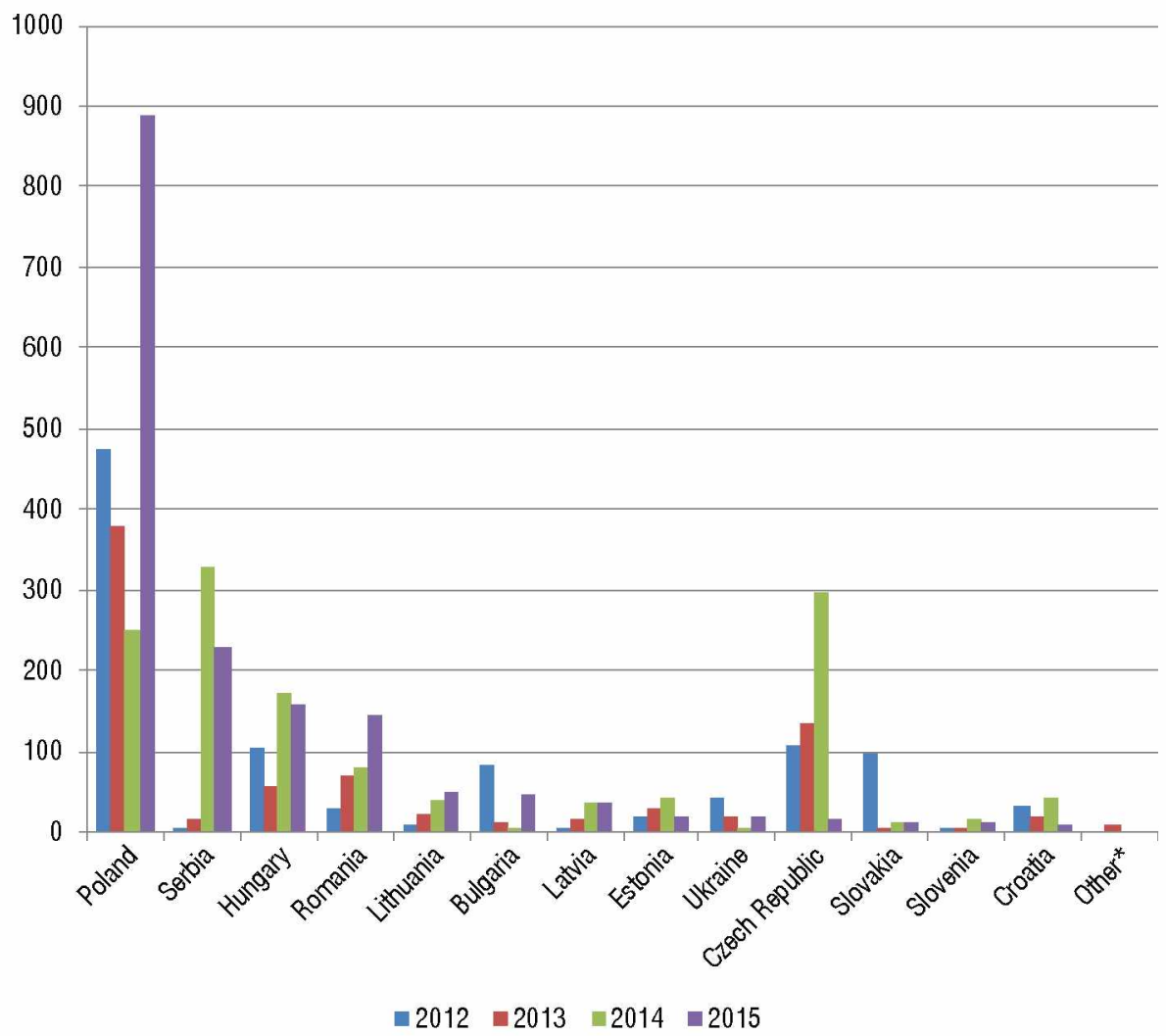

Source: the authors' calculations based on data from the European Private Equity Activity Data 2007-2015, Invest Europe Research, 6 May 2016, https://www.investeurope.eu/media/476271/2015-European-Private-Equity-Activity. pdf, accessed on 10.02.2017.

We need to bear in mind that as a result of the transition from the planned to market economy until 2004 economies of Central and Eastern Europe grew much faster than their Western European counterparts. In the opinion of the European 
Investment Funds, the CEE region is not homogenous and its countries differ substantially with respect to their development level. On the one extreme, there are: Poland, the Baltic States and the Czech Republic, which follow Western European standards, while on the other end there are countries like Bulgaria or Romania, which have a lot to do to catch up. In terms of investment, value-wise Poland ranks first (54\% of total investment) followed by Serbia (14\%), Hungary (10\%) and Romania (9\%). Investment projects in these four countries account for $85 \%$ of all investment projects in the CEE region. This is well illustrated in Diagram 1, showing the value of private equity investment in the Central and Eastern European region from 2012 to 2015.

In 2015 the value of private equity funds in the CEE region amounted to EUR $1.6 \mathrm{bn}$ and increased by $25 \%$ compared to the previous year (the highest growth from 2009). In the same year, in total 312 enterprises from the region used private equity funds and investment from Central and Eastern Europe represented 3.4\% of total private equity investment in the European market (measured as a percentage of GDP it was $0.127 \%$ compared to the European average $0.302 \%)^{3}$.

\section{Diagram 2. Value of exit transactions and private equity investment in Poland (in million EUR)}

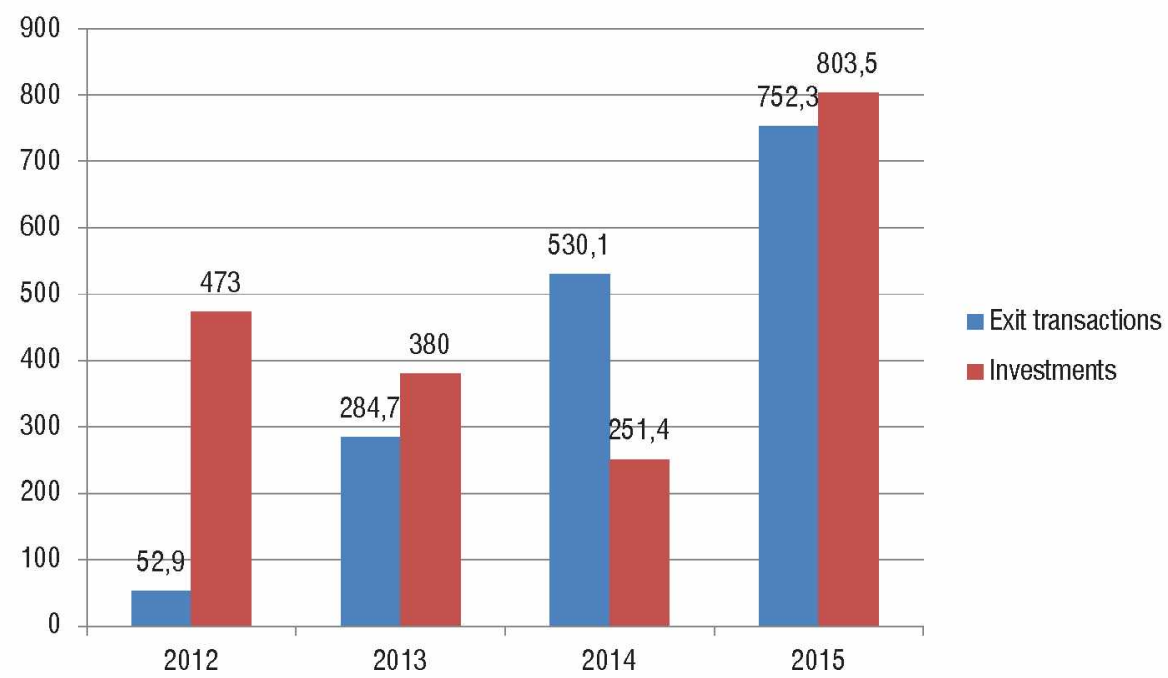

Source: Private Equity in Poland 2016. Trends and Opportunities, KPMG Report, Edition 2016, https://assets.kpmg. $\mathrm{com} / \mathrm{content} / \mathrm{dam} / \mathrm{kpmg} / \mathrm{pdf} / 2016 / 06 / \mathrm{pl}$-raport-kpmg-rynek-private-equity-w--polsce-2016. pdf [Polish language version], accessed on 22.03.2017, p. 15.

3 Central and Eastern European Private Equity Statistics 2015, Invest Europe Research August 2016, https://www.investeurope.eu/media/504370/invest-europe-cee-statistics-2015.pdf, p. 13, accessed on 20.02.2017. 
Value-wise, 2015 was the best year for Poland in terms of private equity investment. According to the data provided by the European Private Equity and Venture Capital Association (EVCA), private equity funds invested ca. EUR $800 \mathrm{~m}$ and exceeded by $7 \%$ the value of exit transactions, which amounted to ca. EUR $750 \mathrm{~m}$. Currently, a major recovery is observed in the investment market in Poland, compared to the previous years when investment was limited primarily to portfolio management and exits from ongoing investments, as demonstrated in Diagram $2^{4}$.

\section{Analysis of the Polish Private Equity Market as the Major Market in the CEE Region}

Poland is the largest and the most populated country in Central and Eastern Europe; it is also the financial centre of the region (the Warsaw Stock Exchange is among the leaders with the highest number of IPOs). Remarkably, the Polish banking sector in its exit strategy from the financial crisis did not engage resources from the central budget. Private equity funds, which invest in our country, benefit from increasing internal demand and the growth of exports.

Diagram 3. Y/Y GDP change in Poland and in the Eurozone (\%) in the period 2012-2017

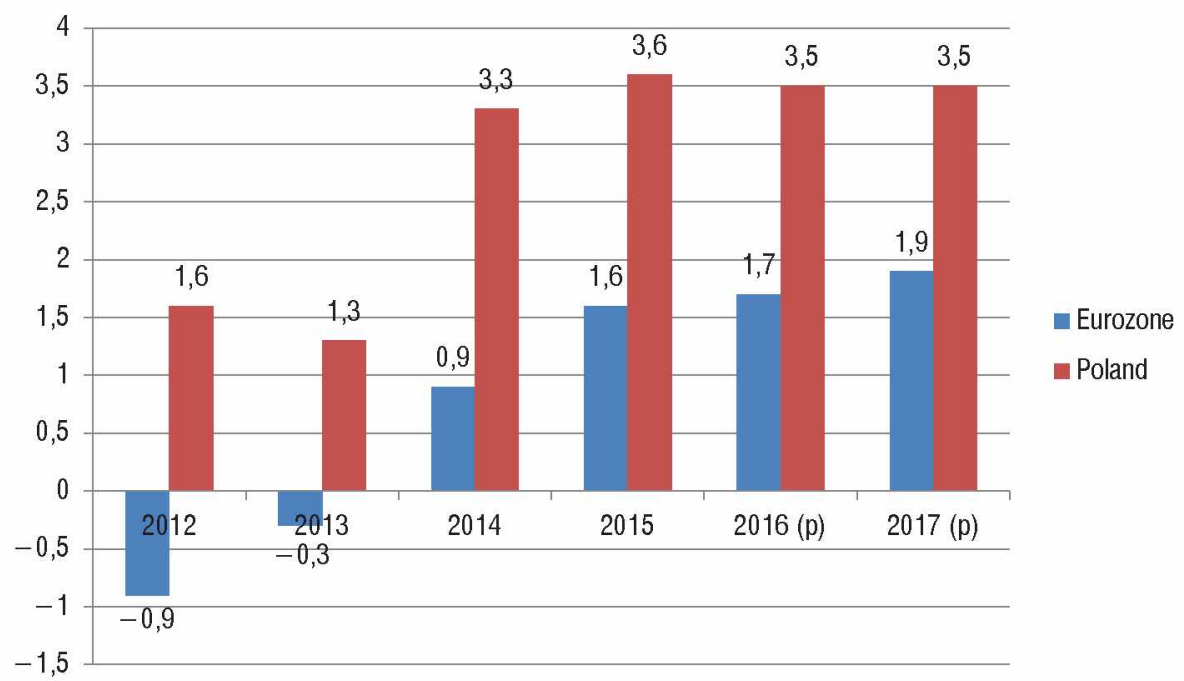

Source: the authors' calculations based on Eurostat data, http://ec.europa.eu/eurostat/, accessed on 15.03.2017.

4 Private Equity in Poland 2016..., op.cit., pp. 14-15. 
As demonstrated in Diagram 3, the effects of the economic downturn resonated across all of the European Union. Yet, Poland was the only Member State who grew over that period. Forecasts of the European Commission suggest that Poland will grow at a rate higher than the eurozone. At the moment Poland is the only economy whose GDP has continued to grow in real terms since $1992^{5}$.

According to data published in the report of the European Commission on the development of small and medium-sized enterprises, entrepreneurship in Poland is above the EU-average and over the past few years SMEs population has substantially increased. We need to note that investments by private funds in Poland were much more stable than in the "old" EU Member States (who reported significant drops after 2008) .

Diagram 4 confirms that entrepreneurship depends on exports, currently 2.5 times higher than when Poland joined the European Union. The continuously developing domestic market is another relevant factor as Poland has recently recorded the highest growth in consumption in the EU. Compared to other economies from the CEE region, the consumption index for Poland is relatively stable.

Diagram 4. Polish exports (in billion EUR) in the years 2012-2015

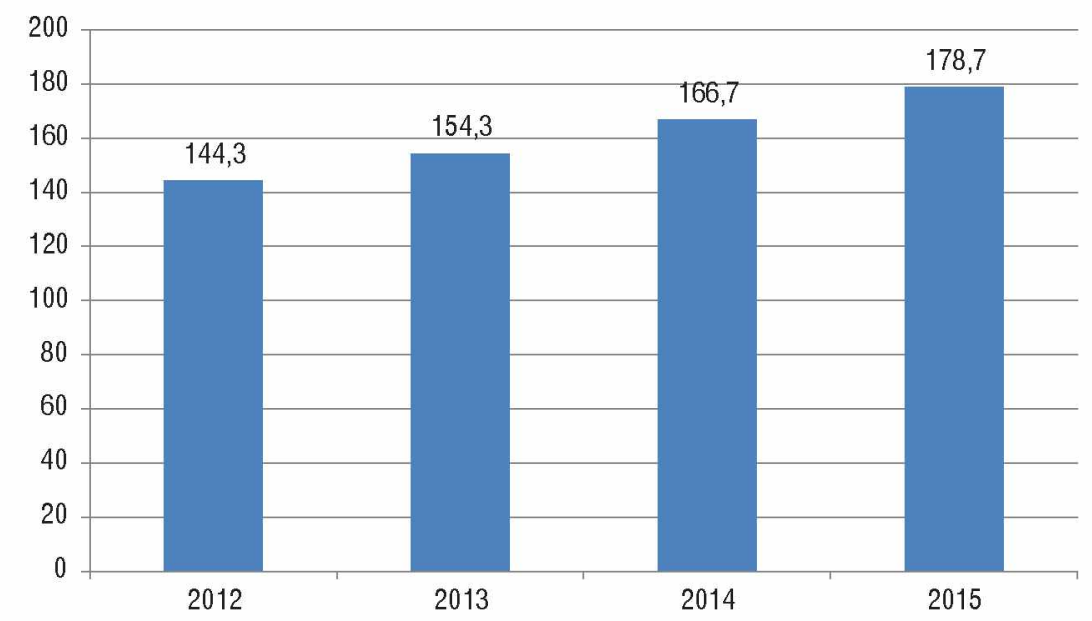

Source: the authors' calculations based on Eurostat data, http://ec.europa.eu/eurostat/, accessed on 15.03.2017.

The value of private equity funds in the CEE region is still very low compared to most Western European economies. In the case of GDP growth, we might expect

\footnotetext{
5 Private Equity in Poland: Facts and Opinions..., op.cit., p. 14.

6 Ibidem, p. 16.
} 
higher private equity investments. Noteworthy, private equity investment in Poland in 2015 represented $0.19 \%$ and the country ranked 14 in Europe, which is illustrated in Diagram 5 that presents also investments in other European countries ${ }^{7}$.

\section{Diagram 5. Private equity investments in Europe in 2015 in relation to GDP}

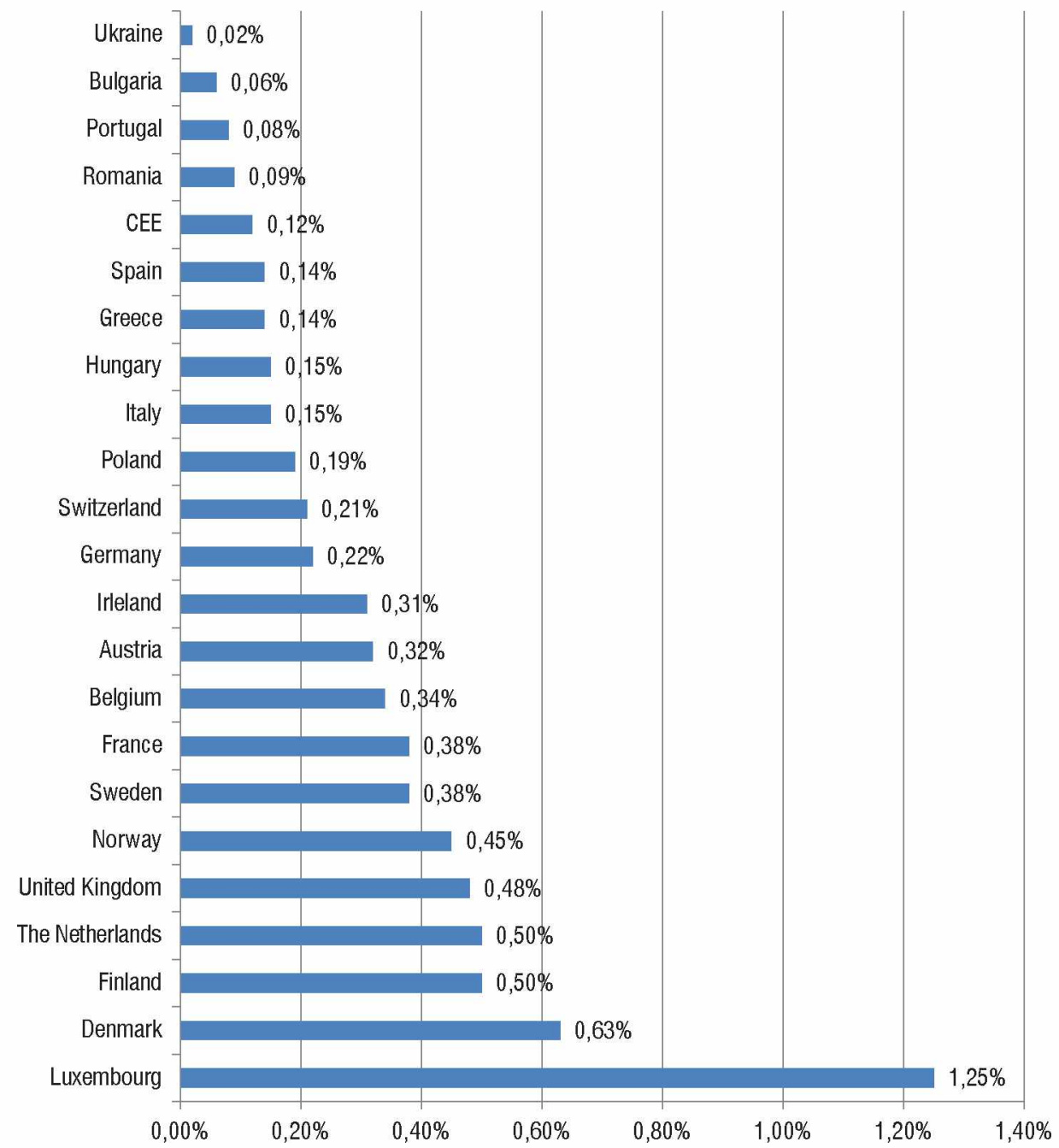

Source: the author's calculations based on data from Private Equity in Poland 2016. Trends and Opportunities, KPMG Report, Edition 2016, https://assets.kpmg.com/content/dam/kpmg/pdf/2016/06/pl-raport-kpmg-rynek-private-equityw--polsce-2016. pdf, accessed on 22.03.2017, p. 16.

7 Private Equity in Poland 2016..., op.cit, p. 16. 
Yet, private equity market in Central and Eastern Europe is relatively young compared to well-developed Western European economies or the United States. Their portfolios include big enterprises from the sectors such as, e.g., technology, the media, medicine, telecommunications and logistics, side by side with medium-sized companies offering innovative products and services (start-ups).

\section{Development Outlook for the Private Equity Market}

Questionnaire studies conducted by the $\mathrm{KPMG}^{8}$ consulting company have shown a new trend among private equity funds in the Polish market, the so called delisting, i.e. an increasingly bigger share of companies intending to exit the public market, which is also due to the shifting of resources from private retirement schemes (in Polish: OFE (literally: open retirement funds) to the Polish Social Insurance Institution (Polish abbr. ZUS) and diminishing popularity of the stock exchange. Nowadays, it is much more difficult to raise capital at the stock exchange and entrepreneurs are more and more inclined to use private equity funds as a potential IPO alternative?. Private equity market in Poland is growing every year and privatisation of state-owned companies has become much less attractive ${ }^{10}$.

The analysis shows that the outlook for the growth of the private equity market is very promising. As indicated above, there is a relationship between GDP per capita and private equity investment (higher GDP translates into higher private equity funds). It is expected that in the future Polish private equity market will be as strong as that in Germany or France ${ }^{11}$.

However, such estimates are relatively highly risky considering previous Polish experiences often stimulated, unfortunately, by the unwillingness of many private equity funds to finance development projects. The climate of risk surrounding various investment projects successfully discourages potential investors from engaging in such ideas even if they represent a high development potential.

The European Investment Fund belongs to the European Investment Bank Group and a major investor in private equity funds in Europe, whose goal is to support small and medium-sized enterprises in Europe. The fund invests in the SME sector using also venture capital. Since 1999 it has operated across the whole CEE region (in Poland since 2001).

\footnotetext{
8 The study involved 26 funds representative of the private equity sector.

9 Initial Public Offering - making a public offering on the stock exchange for the first time.

${ }^{10}$ Private Equity in Poland 2016... op.cit., p. 26.

${ }^{11}$ Private Equity in Poland: Facts and Opinions..., op.cit., pp. 39-40.
} 
Undoubtedly, 2016 was meaningful for the international private equity market when it comes to fundraising. In January 2017 the value of private equity funds addressed to enterprises amounted to USD 45 bn, i.e. $78 \%$ more than the year before (in 2015 the amount was USD 25 bn) ${ }^{12}$. Diagram 6 shows the value of private equity funds globally over the period 1996-2016.

Diagram 6. Value of global private equity funds in the period 2012-2016

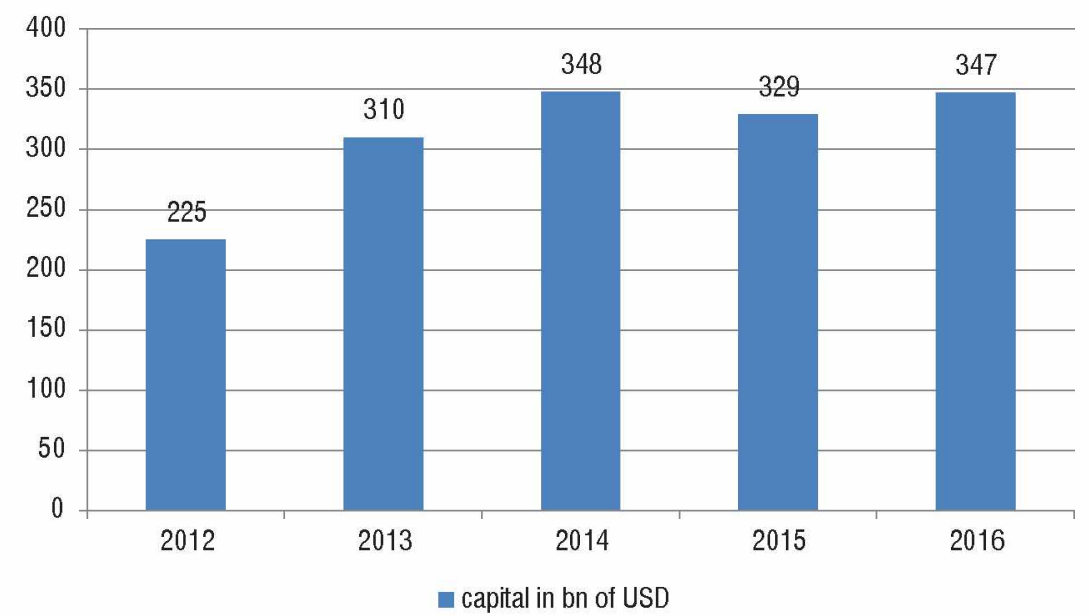

Source: the authors' calculations based on: 2017 Global Private Equity and Venture Capital Report, Preqin, 2017, https:/www.preqin.com/item/2017-preqin-global-private-equity-and-venture-capital-report/1/16504, accessed on 20.03 .2017 , p. 30 .

Recently, the sector has attracted many powerful investors who seek stable profits and possibilities to invest substantial amounts of capital. The latest presidential elections in the United States and Donald Trump's victory boosted investors' interest when the administration announced infrastructure will be their priority and they will increase its financing. CEOs of the biggest alternative asset management companies have revealed their plans to increase private equity funds, which may suggest that 2017 may be the record breaking year for raising private equity capital.

We need to realise that private equity companies accumulate their capital much more quickly than in the past. According to the Preqin report, in 2016 private equity funds needed 16 months from the launch to the final close (for comparison, in 2015 it took them 17 months and in 2013-18 months). Buyout and infrastructure

12 Private Equity Capital Briefing. Monthly Insights and Intelligence on PE Trends, Ernst and Young, February 2017, http://www.ey.com/Publication/vwLUAssets/ey-pe-capital-briefing-february-2017/\$FILE/ ey-pe-capital-briefing-february-2017.pdf, accessed on 10.04.2017, p. 4. 
funds are currently in the highest demand and they close within 12 and 15 months, respectively ${ }^{13}$.

As stated in the KPMG Report ${ }^{14}$, private equity funds in Poland will primarily invest in enterprises in the middle stage of their development, seeking money for further growth. Most of the surveyed enterprises assessed the access to debt financing as good and experienced no problems in receiving it, which is why they realise that the collaboration with private equity funds offers them better prospects to enter international markets.

\section{Conclusion}

In Europe, Poland is considered a leader in private equity market development in the CEE region due to, inter alia, the relatively stable economic performance over the years of the financial crisis (unlike most EU Member States), a well-functioning Stock Exchange, and the precisely specified exit strategy. Noteworthy, until 2004 funds operating in the CEE region reported much better results than those from Western Europe. Currently, Poland is no longer perceived as an emerging economy since the country has already fully embraced Western European standards. Private equity market in Poland holds a strong position in the CEE region and almost half of private equity investments are located in the country.

The above presented data confirms that Poland is an attractive destination for private equity investors. Its economy offers ${ }^{15}$ :

1. growing consumption, i.e. access to a receptive market with a high growth potential (Polish market accounts for $1 / 3$ of the whole CEE region), which translates into dynamic development of many industries;

2. the best developed capital market in Central and Eastern Europe, which impacts economic growth (our economy is among the fastest developing economies in the EU);

3. a stable banking sector, modern and competitive in the CEE region, which offers relatively easily available debt financing to business;

4. well educated employees capable to actively cooperate with private equity funds;

5. well organised legal and systemic foundations that meet international standards and protect investors' interests.

\footnotetext{
${ }_{13}$ Global Private Equity and Venture Capital Report, Preqin, 2017, https://www.preqin.com/item/2017preqin-global-private-equity-and-venture-capital-report/1/16504, accessed on 20.03.2017, p. 52.

14 Private Equity in Poland 2016..., op.cit.

${ }^{15}$ Private Equity in Poland: Facts and Opinions..., op.cit., p. 19.
} 
According to the survey conducted by the $\mathrm{KPMG}^{16}$ consulting company, private equity funds in Poland enjoy double or even triple return on investment. Polish market offers good growth prospects because of its advantages discussed above, which are expected to attract even more investors. Clearly, when formulating optimistic outlooks we need to be rather cautious about the assessment of developments when it comes to the economic situation. Especially, when risk analyses performed by private equity funds are quite subjective and qualitative by nature. As a result, declarations made by their representatives about being ready to support interesting projects quite often remain empty words.

In the light of the analysis, which has taken account of diverse reports, we may conclude that private equity funds will grow dynamically in the forthcoming two years and it seems justified to say that Poland is one of the most promising markets in Central and Eastern Europe in terms of the number of profitable takeovers, which are expected to grow in the near future.

\section{Bibliography}

1. Central and Eastern European Private Equity Statistics 2015, Invest Europe Research August 2016, https://www.investeurope.eu/media/504370/invest-europe-cee-statistics-2015.pdf, accessed on 20.02.2017.

2. http://ec.europa.eu/eurostat/, accessed on 15.03.2017.

3. European Private Equity Activity Data 2007-2015, Invest Europe Research, 6 May 2016, https://www.investeurope.eu/media/476271/2015-European-Private-EquityActivity.pdf, accessed on 10.02.2017.

4. 2015 European Private Equity Activity. Statistics on Fundraising, Investments and Divestments, Invest Europe Research, 6 May 2016, https://www.investeurope. eu/ media/476271/2015-European-Private-Equity-Activity.pdf, accessed on 15.03.2017.

5. 2016 Global Private Equity and Venture Capital Report, Preqin, 2016, https://www. preqin.com/docs/samples/2016-Preqin-Global-Private-Equity-and-Venture-Capital-Report-Sample_Pages.pdf, accessed on 20.03.2017.

6. 2017 Global Private Equity and Venture Capital Report, Preqin, 2017, https:// www.preqin.com/item/2017-preqin-global-private-equity-and-venture-capital -report/1/16504, accessed on 20.03.2017.

${ }^{16}$ Private equity in Poland: Facts and Opinions..., op.cit. 
7. Private Equity, Public Exits Q4 2016 Digital Edition, Ernst and Young, February 2017, http://www.ey.com/Publication/vwLUAssets/EY-private-equity-q4-2016-info graphic/\$File/EY-private-equity-q4-2016-infographic.pdf, accessed on 20.03.2017.

8. Private Equity Capital Briefing. Monthly Insights and Intelligence on PE Trends, Ernst and Young, February 2017, http://www.ey.com/Publication/vwLUAssets/ey-pecapital-briefing-february-2017/\$FILE/ey-pe-capital-briefing-february-2017.pdf, accessed on 10.04.2017.

9. http://psik.org.pl/pl, accessed on 10.03.2017.

10. Private Equity in Poland: Facts and Opinions, KPMG Report, Edition 2014, https:// assets.kpmg.com/content/dam/kpmg/pdf/2014/06/Rynek-Private-Equity-w-Polscefakty-a-opinie-2014-KPMG-w-Polsce.pdf [Polish language version], accessed on 22.03.2017

11. Private Equity in Poland 2016. Trends and Opportunities, KPMG Report, Edition 2016, https://assets.kpmg.com/content/dam/kpmg/pdf/2016/06/pl-raport-kpmg-rynekprivate-equity-w--polsce-2016.pdf [Polish language version], accessed on 22.03.2017.

12. Wiza R., Rynek private equity w Polsce 2016, https://home.kpmg.com/pl/pl/home/ insights/2016/06/rynek-private-equity-w-polsce-trendy-szanse-rozwoju-rafal-wiza. $\mathrm{html}$, accessed on 20.02.2017. 